Article

\title{
Identify Ecological Corridors and Build Potential Ecological Networks in Response to Recent Land Cover Changes in Xinjiang, China
}

\author{
Yanjie Zhang ${ }^{1,2}$ and Wei Song ${ }^{2, *(1)}$ \\ 1 College of Tourism and Urban-Rural Planning, Chengdu University of Technology, Chengdu 610059, China; \\ zhangyanjie_cdlg@yeah.net \\ 2 Key Laboratory of Land Surface Pattern and Simulation, Institute of Geographic Sciences and Natural \\ Resources Research, Chinese Academy of Sciences, Beijing 100101, China \\ * Correspondence: songw@igsnrr.ac.cn
}

Received: 8 September 2020; Accepted: 26 October 2020; Published: 28 October 2020

check for updates

\begin{abstract}
Using Linkage Mapper corridor simulation software, which is based on minimum cost distance, we identify ecological corridors and build potential ecological networks in response to recent land cover changes in Xinjiang, China. Based on the analysis of land use/cover changes, the change of landscape pattern index is also calculated. The results show that: (1) During the year 2000-2015, cultivated land and built-up areas of Xinjiang showed an increasing trend. Due to urbanization, Xinjiang's landscape connectivity is getting worse, and the landscape is becoming more and more fragmented and isolated. (2) We have constructed 296 ecological corridors, with a total length of $2.71 \times 10^{4} \mathrm{~km}$ and an average corridor length of $90.98 \mathrm{~km}$. A total of 145 ecological source patches and 500 ecological nodes were connected by 296 ecological corridors. (3) The ecological corridor of Xinjiang presents the characteristics of "dense-north and sparse-south" in space. The areas with dense distribution of ecological corridors mainly include Urumqi, Changji, Turpan, Tacheng, Kizilsu Kirgiz, Karamay, and Yining, and the Taklimakan desert fringe. The sparse distribution is mainly in the whole Taklimakan desert.
\end{abstract}

Keywords: landscape pattern; land use changes; ecological network; Xinjiang; China

\section{Introduction}

A series of human activities, such as land development around the world, constantly changes the original form of the earth's surface, resulting in the loss or occupation of a large number of animal and plant habitats, the fragmentation of natural landscape, and the poor connectivity of patches, which increased the ecosystem degradation [1-5]. Since the reform and opening up, China's rapid urbanization has led to a significant decline in the ecological land, resulting in ecological landscape fragmentation and isolation [6-8]. Fragmentation between habitat patches caused by ecological landscape fragmentation is a great threat to biodiversity conservation [9-11]. The continuity of habitat patches in the ecosystem has attracted more and more attention [12,13]. Building and strengthening ecological corridors and ecological networks have become important tools [14-16] to enhance ecosystem service function.

An ecological network is the channel of ecosystem material circulation, energy flow, and information transmission in the ecosystem. An ecological network consists of three landscape pattern elements: Ecological source, ecological corridor, and ecological node $[17,18]$. The ecological network structure integrity determines the level of function $[19,20]$. The ecological network connects the broken habitats through ecological corridors and ecological nodes to form a complete landscape network to ensure all ecological security. 
The term ecological corridor first appeared in the field of biology. By 1975, Wilson and Willis proposed corridor connections to mitigate the negative effects of habitat fragmentation [21]. For the first time in 1980, the International Union for Conservation of Nature (IUCN) proposed the viewpoint of applying ecological corridors to global conservation strategies [22]. Ferenz Jordan formally proposed a method to study ecological corridors from the point of view of reliability theory in 2000 and analyzed the probability of successful species migration in the landscape network of ensemble population composed of habitat, stepping stone, and corridor [23]. The ecological source itself has the characteristics of landscape connectivity and spatial expansion. Ecological sources not only play an important role in promoting the development of landscape ecology, but also are the origin or aggregation of ecosystem material circulation, energy flow, and information transmission. The ecological node is the energy output, which plays the role of engine in the whole ecological network. Correct classification of ecological sources can make the extracted ecological network more accurate [24].

At present, the ecological network is mainly constructed by combining ecological corridor software with the ecological landscape model. Taking Wuhan for example, Tang et al. [25] constructed an integrated ecological network of birds and small terrestrial mammals, using the Integrated Valuation of Environmental Services and Tradeoffs (InVEST) and the least cost path model (LCP), combined with the cost surface affected by habitat element, geophysical landscape, and human disturbance. Shi et al. [26] used Graphab software to establish an ecological network based on global landscape heterogeneity analysis. In the construction of the ecological network, the identification of ecological sources and the determination of resistance surface, they utilized Morphological Spatial Pattern Analysis (MSPA) and Structural Equation Model (SEM). Li et al. [27] used FRAGSTATS 3.3 software, combined with the actual situation of the case and network analysis method, to construct the ecological network of the two sides of the river and the north and south of Nanchang City, China. Zhao et al. [28] took Tianjin, China as an example, based on the landscape pattern analysis, constructed the Tianjin urban ecological network by using the minimum cost distance model. The results show that the optimized Tianjin urban ecological network greatly improves the connectivity of urban corridors.

The difficulty of constructing the ecological network is to construct a resistance surface. Resistance surface indicates the resistance or expected difficulty of species passing through ecological patches [29]. For resistance surface construction, the commonly used methods are biological behavior resistance estimation, expert score, entropy weight, and landscape development intensity index method [7,30-32]. Some scholars take Changzhou City as an example to construct the ecological network based on habitat quality evaluation. The results show that the resistance surface based on habitat quality is more suitable for corridor simulation [1]. From the view of the resistance surface constructed in the past, the construction of most resistance surfaces only considers the factor of land use type, and rarely considers the influence of road, river, and elevation [33].

The ecological corridor can be divided into the forest ecological corridor [34], wetland ecological corridor [35], desert ecological network [36], and urban ecological corridor [37-40] according to the difference of ecosystem. In general, there are many related studies on urban ecological corridors in the past. Urban ecological corridor refers to the linear or zonal ecological landscape with natural habitat, green open space, or human settlement isolation function in the artificial ecological environment of the city or urban [41,42]. Urban ecological corridors (such as traffic green corridors) have an important impact on the urban ecological environment. For example, urban or inter-city green belts can not only accelerate the flow of natural species, but also effectively isolate or filter environmental pollution. There are various types of urban corridors [43]. According to the structure, urban corridors can be divided into five types: River corridor [44], green traffic corridor [45], biodiversity conservation corridor [46], heritage corridor, and recreation corridor [47,48]. According to the function differences, urban corridors can be divided into barrier corridors and communication corridors. The barrier corridor is an obstacle for biodiversity conservation and population diffusion [49], while the communication corridor is an important channel for water, nutrients, energy, plants, animals, and other elements to flow into various ecosystems [50]. From the development of urban ecological corridor in the world, since the 
20th century, the green road planning in the United States has developed into a mufti-functional ecological corridor planning tool. From the planning level, the green road planning has developed from the regional level to the national level [51]. Since the 1960s, urban ecological corridor planning in the United States has been the leading level in the world. Influenced by the idea of American Green Road, Europe began to build a large-scale ecological corridor from the 1990s. The conceptual framework of European ecological network (EECONET) was established in the early 21st century, which emphasizes the network construction based on landscape ecological connectivity [52,53]. In general, the urban ecological corridor construction in the United States aims to protect the natural landscape, while the urban ecological corridor construction in Europe focuses on the protection of biodiversity.

The construction of the ecological corridor in China started later than that in western developed countries, and mainly focused on the construction of urban ecological corridor. After 1990, the Chinese government began to attach great importance to the construction of urban ecological corridors, and the "Notice on Further Promoting the National Green Construction" [54] issued by the State Council of China set off an upsurge in the construction of urban ecological corridors. Especially in the developed areas of China, more and more research focused on the construction of ecological corridors. Cities such as Beijing and Shanghai have taken the construction of ecological corridors as an important part of urban planning and management, forming various green corridors of roads and railways, and multi-scale riverbank ecological corridors. For example, the 2010-2020 overall plan of ecological city in Guangzhou, China, emphasizes the construction of seven ecological corridors. Similarly, China's Nanjing City [55], Jinan City [56], Hunan Province [57], Jiangsu Province [58], and other places have carried out urban ecological network construction. It can be seen that the construction of China's ecological network is mostly carried out in economically developed places. However, for the ecologically fragile areas in the west, the planning of ecological corridors is still very low.

In previous researches, methods of mapping ecological corridors usually include circuit theory, resistant kernel, and individual-based modeling. Circuit theory determines ecological connectivity by simulating a random walker moving from a power source, passing through a resistive surface, and reaching a destination (ground). This method does not consider cost and is time-consuming and labor-intensive. Resistant core is based on the lowest moving cost from all locations on land or sea, and can be implemented using kernel (moving window) method. This method calculates the relative density of scattered individuals at the source location. Modeling based on individuals simulates the path of movement of individuals based on assumed rules. It can estimate the relative use frequency. However, this method does not consider the cost. Linkage Mapper is a software that can be used by planners to make decisions, and is a popular tool for analyzing the connectivity of biological habitats. The tool can identify the importance of ecological corridors, important nodes and key barriers, and can analyze the impact of climate change on biological habitats and biodiversity. Therefore, this paper adopts the minimum cost distance model to construct the ecological corridors in Xinjiang with Linkage Mapper corridor software.

In general, in the past for the construction of ecological networks in China, more research is carried out in urban ecological network planning. Moreover, the construction of ecological networks is mostly concentrated in developed areas. However, for the relatively fragile areas of the ecosystem, there is still a lack of related research on ecological corridors and network construction. In view of this, this study takes Xinjiang, the western ecologically fragile area of China, as an example, to carry out the related research of ecological corridor identification and ecological network construction. Specifically, the objectives of this study are: (1) To reveal land use/cover changes and landscape pattern changes in Xinjiang from 2000 to 2015; (2) to identify the ecological corridors of Xinjiang using Linkage Mapper corridor simulation software; (3) to construct the ecological network of Xinjiang using the data of identified ecological corridors and ecological nodes. 


\section{Study Area and Data Sources}

\subsection{Study Area}

Xinjiang lies in the northwest of China (Figure 1), locating between $34^{\circ} 25^{\prime} \sim 49^{\circ} 10^{\prime}$ north latitude and $73^{\circ} 40^{\prime} \sim 96^{\circ} 23^{\prime}$ east longitude. The land accounts for about one sixth of China's land. The maximum width between north and south of Xinjiang is $1650 \mathrm{~km}$, and the maximum length between west and east of Xinjiang is $2000 \mathrm{~km}$. It is the largest province in China, with a total of 1.66 million $\mathrm{km}^{2}$. Because of the large territory, the climatic conditions in Xinjiang vary greatly. Average annual temperature in Xinjiang is $9.7^{\circ} \mathrm{C}$, and among them, the average annual temperature in northern Xinjiang is $7.4{ }^{\circ} \mathrm{C}$, while it is $12.4^{\circ} \mathrm{C}$ in southern Xinjiang. Average annual precipitation in Xinjiang is $168.5 \mathrm{~mm}$, and among them, the average annual precipitation in northern Xinjiang is $238.1 \mathrm{~mm}$, while it is $95.8 \mathrm{~mm}$ in southern Xinjiang. The southeast of the study is connected with Gansu, Qinghai, and Tibet, while the northwest is adjacent to Mongolia, the southwest is adjacent to Afghanistan, Pakistan, and India, and the west is bordering Russia, Kazakhstan, Kyrgyzstan, and Tajikistan. Xinjiang is far away from the ocean with mountains and basins whose topography and geomorphology can be summarized as "Two Basins Surrounded by Three Mountains". From north to south, the representative mountains are Mount Altai, Mount Tian, and Mount Kunlun. Mount Tian lies in the center, which divides Xinjiang into two parts: Junggar Basin in the north and Tarim Basin in the south. Among them, the Tarim Basin is the largest basin in China, with an area of 530,000 square kilometers.

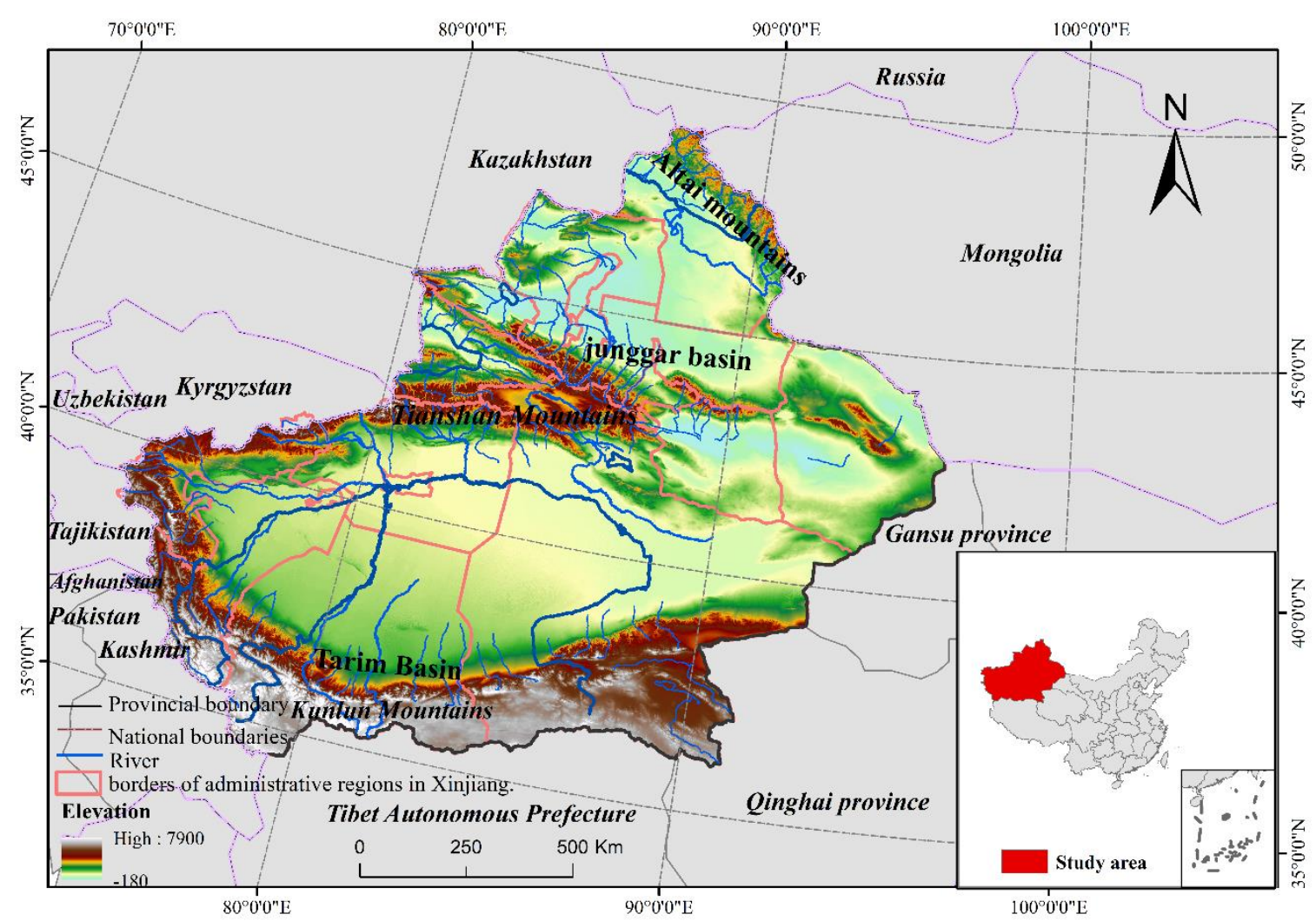

Figure 1. Location of Xinjiang, China.

\subsection{Data Sources}

This paper uses three types of data. The first is land use data. The second is geographical element data, including surface cover data, DEM, drainage, and road data. The last is ecological source data, including scenic spots, forest parks, geological parks and protected zone data, etc. The land use data adopted in this paper are the data of 2000 and 2015 with a resolution of $1 \mathrm{~km}$, from the remote sensing monitoring data of land use status in China [59]. According to the remote sensing monitoring 
database of land use status in China, the land use types in this data include six primary types and 24 secondary types. The DEM data is from the geospatial data cloud with an accuracy of $1 \mathrm{~km}$ [60]. Data on drainage and nature reserve are from the resource and environment data center of Chinese Academy of Sciences [61]. Land cover data are derived from a geographic monitoring cloud platform with a resolution of $1 \mathrm{~km}$ [59]. The data of road, scenic spots, forest parks, and geological parks are obtained by using a web python programming crawler program [62], and then the 91 map tools and GIS tools are used for post-data processing.

\section{Research Methods and Technical Routes}

\subsection{Technical Route}

The design of the research is as follows: First, the land uses in Xinjiang in 2000 and 2015 were analyzed. Then, fragstats 4.2 software was used to get the landscape pattern index of Xinjiang in 2000 and 2015, including perimeter fractal dimension index, patch density, percentage of patch, cohesion index, landscape separation index, and aggregation index. Next, according to the distribution map of land use type, the corresponding resistance surface is determined. Depending on the type of landscape, we give the corresponding resistance, and the landscape resistance surface is determined. Meanwhile, nature reserves, geological parks, scenic spots, and forest parks were found by using reptile big data [62], and were made as ecological source vector data. Finally, by using Linkage Mapper corridor simulation software and the minimum cost distance model, the accumulated resistance surface and ecological corridor are obtained according to the comprehensive resistance surface (raster data) and ecological source (vector data). Finally, we generate the ecological network of Xinjiang by using GIS technology to extract potential ecological corridors, ecological nodes, and ecological source data (Figure 2).

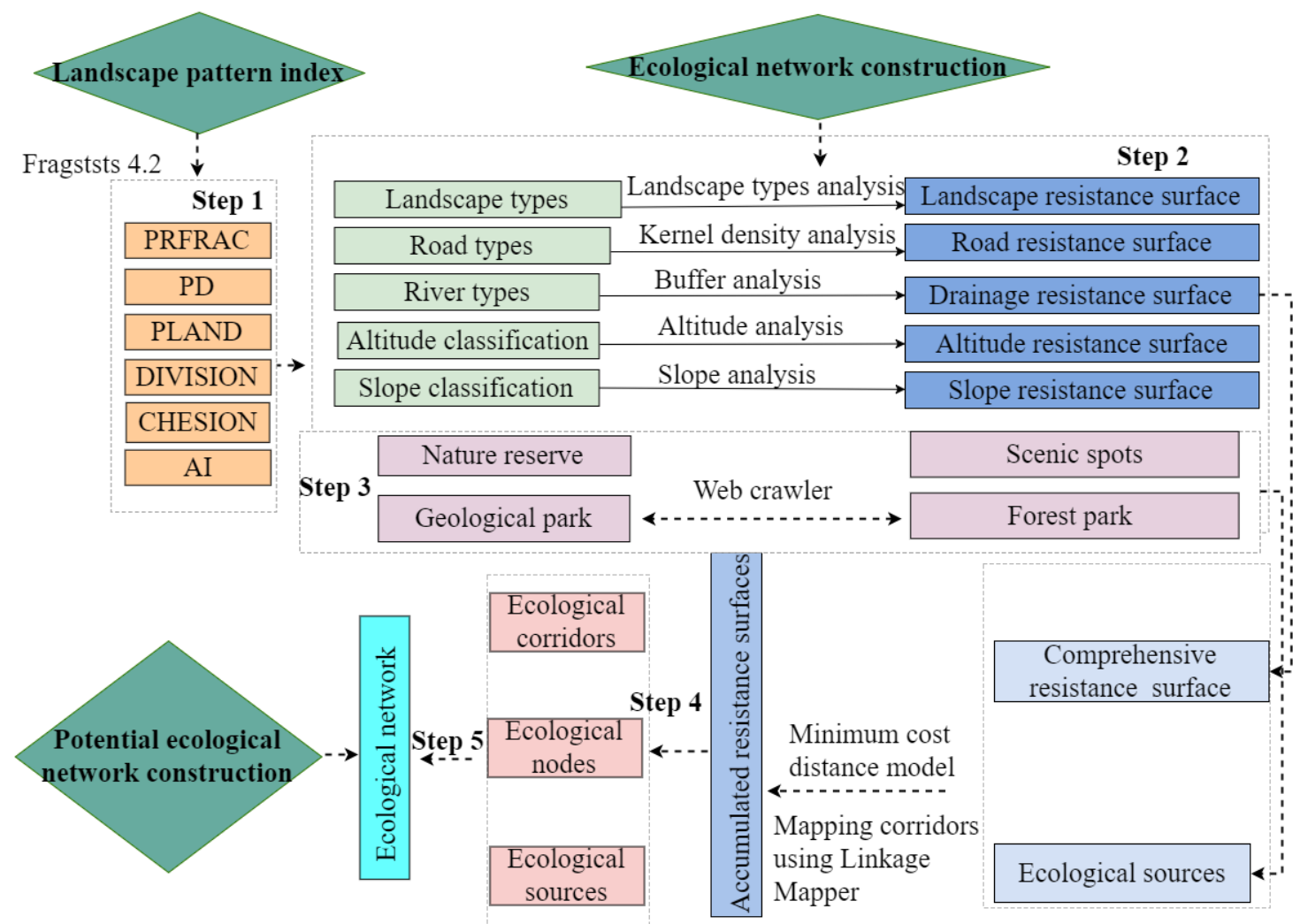

Figure 2. Technical route of mapping ecological corridor in Xinjiang. Notes: PRFRAC is perimeter fractal dimension index; PD is patch density; PLAND is landscape patch; DIVISION is landscape dimension index; $\mathrm{CHESION}$ is patch cohesion index; $\mathrm{AI}$ is aggregation index. 


\subsection{Methodology}

\subsubsection{Dynamics Changes in Land Use}

According to the cultivated land change intensity index of relevant experts and scholars [63], the variation intensity index of surface cover types in 2000 and 2015 is calculated. The calculation formula is as follows:

$$
\text { LTI }=\frac{\mathrm{A}_{2}-\mathrm{A}_{1}}{\mathrm{~A}} \times \frac{1}{\mathrm{~T}} \times 100 \%
$$

where, LTI is the variation intensity index of the quantity of a certain surface cover type in the study period. $A_{1}$ is the initial study for a surface cover type, while $A_{2}$ is the end study for a certain surface cover type. A is the total area of the study area, and $\mathrm{T}$ is the time between the end and the initial stage of the study.

\subsubsection{Determine the Landscape Patch Resistance}

The movement of species between different ecological sources should overcome some resistance. The difficulty of running the minimum cost distance model is determining the resistance value of landscape patches. Different resistance assignments will produce different simulation results for the ecological corridor. Therefore, the reasonable resistance value is an important prerequisite for the construction of the ecological network. Generally speaking, there are almost no species in permanent glaciers and snowfields. Therefore, the resistance value is not considered for the time being, and was set to zero. For arbor-shrub grassland, the larger the area, the richer the species, the higher the biodiversity, the higher the ecological suitability, and the smaller the corresponding resistance value. Like the sandy land and the Gobi, the natural conditions are relatively harsh and the biodiversity is low, so the greater the resistance that species encounter when they pass through. The resistance value of the river is set through buffer zones of different levels and distances. Generally speaking, the greater the buffer distance, the greater the resistance that species will encounter when passing through, so the greater the resistance value. The wider the width of the road, the less conducive to species migration, and the greater the corresponding resistance. In terms of slope and elevation, the greater the slope or the higher the altitude, the less conducive to species migration and the greater the resistance value.

Based on the reference of relevant research literature $[25,26,64]$ and the actual situation of the study, this paper finally determines five indexes, such as surface cover type, drainage element, road element, slope element, and elevation element, as the indicators of resistance surface construction, and determines the resistance value in line with Xinjiang landscape pattern (Table 1).

\subsubsection{Build Resistance Surfaces}

\section{Construction of Resistance Surfaces at All Levels}

On the basis of GIS related software, the downloaded DEM data are inlaid and cut, and the distribution map of Xinjiang DEM is obtained. Through the reclassification tool and assignment of each grade, the elevation resistance surface is obtained. The DEM data are extracted by the slope based on GIS related software, then reclassified, and finally assigned to each grade to generate the slope resistance surface. By using the road data in geographical elements and based on the GIS related software, the data of national highways, railways, and other road elements are extracted. The corresponding search radius parameters of the three roads are set, and the road resistance surface is finally generated. Using GIS related software, the drainage data of each grade are assigned separately to generate drainage resistance surface. By using GIS software, a part of the land cover is merged, and referring to the relevant research results, each landscape type is given different resistance values according to the characteristics of the study. Finally, the vector data are converted into $1000 \mathrm{~m} \times 1000 \mathrm{~m}$ raster data to obtain the landscape resistance surface. 
Table 1. Resistance of landscape patches in Xinjiang.

\begin{tabular}{|c|c|c|c|c|}
\hline Indicators & Weight & Classification & Grading & Resistance \\
\hline \multirow{17}{*}{$\begin{array}{l}\text { Elements of } \\
\text { surface cover } \\
\text { type }\end{array}$} & \multirow{17}{*}{0.3} & Type of land use & Subgroups & Resistance Value \\
\hline & & Permanent glacier snow & 1 & 0 \\
\hline & & $\begin{array}{l}\text { Arbor forest, mixed forest, bamboo forest, } \\
\text { natural grassland }\end{array}$ & $>10,000 \mathrm{~km}^{2}$ & 1 \\
\hline & & & $5000-10,000 \mathrm{~km}^{2}$ & 10 \\
\hline & & & $1000-5000 \mathrm{~km}^{2}$ & 50 \\
\hline & & & $20-1000 \mathrm{~km}^{2}$ & 80 \\
\hline & & & $<20 \mathrm{~km}^{2}$ & 100 \\
\hline & & $\begin{array}{c}\text { Shrubs, sparse forestry, sparse thickets, } \\
\text { unused land }\end{array}$ & $>10,000 \mathrm{~km}^{2}$ & 1 \\
\hline & & & $5000-10,000 \mathrm{~km}^{2}$ & 15 \\
\hline & & & $1000-5000 \mathrm{~km}^{2}$ & 50 \\
\hline & & & $20-1000$ km² & 80 \\
\hline & & & $<20 \mathrm{~km}^{2}$ & 100 \\
\hline & & Ditches, lakes, potholes & 1 & 300 \\
\hline & & $\begin{array}{l}\text { urban and rural, industrial and mining, } \\
\text { oil fields, salt fields, quarries and other } \\
\text { land use and traffic roads }\end{array}$ & / & 400 \\
\hline & & Gobi & I & 500 \\
\hline & & Sandy land & 1 & 1000 \\
\hline & & Others & / & 20 \\
\hline \multirow{13}{*}{$\begin{array}{l}\text { Drainage } \\
\text { elements }\end{array}$} & \multirow{13}{*}{0.25} & River classification & Buffer & Resistance Value \\
\hline & & Level 1-3 & $<20 \mathrm{~m}$ & 100 \\
\hline & & & $20-100 \mathrm{~m}$ & 200 \\
\hline & & & $100-500 \mathrm{~m}$ & 750 \\
\hline & & & $500-1000 \mathrm{~m}$ & 1500 \\
\hline & & Level 4 & $<20 \mathrm{~m}$ & 80 \\
\hline & & & $20-100 \mathrm{~m}$ & 180 \\
\hline & & & $100-500 \mathrm{~m}$ & 600 \\
\hline & & & $500-1000 \mathrm{~m}$ & 1500 \\
\hline & & Level 5 & $<20 \mathrm{~m}$ & 50 \\
\hline & & & $20-100 \mathrm{~m}$ & 150 \\
\hline & & & $100-500 \mathrm{~m}$ & 500 \\
\hline & & & $500-1000 \mathrm{~m}$ & 1500 \\
\hline \multirow{4}{*}{ Road elements } & \multirow{4}{*}{0.25} & Roads & Width & Resistance value \\
\hline & & Other roads & $<10 \mathrm{~m}$ & 50 \\
\hline & & National highway & $16 \mathrm{~m}$ & 300 \\
\hline & & Railways & $50 \mathrm{~m}$ & 500 \\
\hline \multirow{7}{*}{ Slope element } & \multirow{7}{*}{0.1} & Slope classification & & Resistance Value \\
\hline & & $<2^{\circ}$ & & 10 \\
\hline & & $2^{\circ}-6^{\circ}$ & & 50 \\
\hline & & $6^{\circ}-15^{\circ}$ & & 150 \\
\hline & & $15^{\circ}-25^{\circ}$ & & 300 \\
\hline & & $25^{\circ}-35^{\circ}$ & & 400 \\
\hline & & $>35^{\circ}$ & & 500 \\
\hline \multirow{9}{*}{$\begin{array}{l}\text { Elevation } \\
\text { elements }\end{array}$} & \multirow{9}{*}{0.1} & Elevation classification & & Resistance Value \\
\hline & & $<500 \mathrm{~m}$ & & 20 \\
\hline & & 500-1000 m & & 50 \\
\hline & & $1000-1500 \mathrm{~m}$ & & 100 \\
\hline & & $1500-2000 \mathrm{~m}$ & & 200 \\
\hline & & $2000-3000 \mathrm{~m}$ & & 400 \\
\hline & & $3000-4500 \mathrm{~m}$ & & 600 \\
\hline & & $4500-6000 \mathrm{~m}$ & & 800 \\
\hline & & $>6000 \mathrm{~m}$ & & 1000 \\
\hline
\end{tabular}


Construction of a Comprehensive Resistance Surface

The value of the comprehensive resistance surface is obtained by the integrated superposition of each resistance surface and the corresponding weight. The weights of each resistance surface in this study were obtained by an analytic hierarchy process combined with expert scoring. The weight of the cover type resistance surface, elevation resistance surface, slope resistance surface, road resistance surface, and drainage resistance surface were $0.30,0.10,0.10,0.25$, and $0.25 \mathrm{in}$ turn. The comprehensive resistance surface is obtained by the weighted superposition of the grid calculator as the cost data of the minimum cost distance model.

\subsubsection{Selection of Ecological Sources}

This paper uses information crawling technology to obtain ecological source data. Based on the tool of a map application programming interface API (Application Programming Interface), crawler technology is development. First, we input the research area names into the POI (Point of Interest) search tool. Then, the latitude and longitude coordinates are obtained by geographical location inverse query and other related means. Finally, the spatial distribution of ecological sources is obtained by GIS software. This research uses a Python programming crawler program to access AutoNavi WEB service, searching for place names related to "Nature Reserve", "Forest Park", "Landscape Garden", and "Geological Park" [62]. These acquired vector data were used in running the minimum cost distance model.

\subsubsection{Minimum Cost Distance Model}

The resistance surface is composed of a set of values that represent the degree of difficulty or the risk level that species may encounter across the region. Generally speaking, the higher the habitat quality or habitat suitability is, the less resistance species will encounter. The minimum cost distance model, which displays the shortest path from ecological source to destination in space, can effectively avoid the interference of external environment and ensure that species can complete migration smoothly and prevent the loss of all biodiversity. The formula is as follows [65-68].

$$
\mathrm{MCR}=\mathrm{f}_{\min } \sum_{\mathrm{j}=\mathrm{n}}^{\mathrm{i}=1}\left(\mathrm{D}_{\mathrm{ij}} \times \mathrm{R}_{\mathrm{i}}\right)
$$

where, MCR represents the minimum cumulative resistance value, and $f$ represents the unknown positive function; $\mathrm{D}_{\mathrm{ij}}$ represents the spatial distance of species from ecological source patches to landscape units $i$; $R_{i}$ represents the resistance coefficient of landscape units $i$ to the movement of some species.

\subsubsection{Accumulated Resistance Surface}

The accumulated resistance surface is generated by Linkage Mapper corridor simulation software [69]. Linkage Mapper corridor simulation software is a GIS tool for analyzing the connectivity of all animal habitats. The main principle of the software is to use the ecological source data and the comprehensive resistance surface data to identify and map the minimum cost relationship between the ecological sources. For each pixel of the integrated resistance graph, there is a fixed value reflecting the difficulty or death risk rate passing through the pixel. Surface cover, drainage, elevation, and other factors determine the magnitude of the resistance value. When the species leave a specific ecological source, the cost-weighted distance produces an accumulated resistance surface map.

\subsubsection{Construction of Ecological Corridor and Ecological Network}

With the support of GIS technology, the ecological corridor is generated by Linkage Mapper software using comprehensive resistance surface and ecological source data. Then the ecological nodes are extracted by the node extraction function in the GIS. Finally, the ecological source, ecological 
corridor and ecological node data of the study are superimposed to construct the ecological network of Xinjiang.

\section{Results}

\subsection{Changes in Landscape Patterns}

We selected six indices of the percentage of landscape patch, patch density, perimeter fractal dimension index, patch cohesion index, landscape dimension index, and aggregation index to analyze the changes of landscape pattern in Xinjiang (Table 2).

Table 2. Landscape pattern index of Xinjiang during 2000-2015.

\begin{tabular}{|c|c|c|c|c|c|c|c|c|c|}
\hline $\begin{array}{l}\text { Landscape } \\
\text { Index }\end{array}$ & Year & Grassland & $\begin{array}{c}\text { Forestry } \\
\text { Areas }\end{array}$ & $\begin{array}{c}\text { Unused } \\
\text { Land }\end{array}$ & $\begin{array}{l}\text { Water } \\
\text { Areas }\end{array}$ & $\begin{array}{l}\text { Cultivated } \\
\text { Land }\end{array}$ & $\begin{array}{c}\text { Sandy } \\
\text { Land }\end{array}$ & $\begin{array}{c}\text { Gobi } \\
\text { Desert }\end{array}$ & $\begin{array}{l}\text { Built-Up } \\
\text { Areas }\end{array}$ \\
\hline \multirow{2}{*}{ PLAND } & 2000 & 29.26 & 2.33 & 22.44 & 3.18 & 3.63 & 21.16 & 17.73 & 0.26 \\
\hline & 2015 & 28.60 & 2.26 & 22.21 & 3.19 & 4.71 & 21.08 & 17.53 & 0.41 \\
\hline \multirow{2}{*}{ PD } & 2000 & 0.0039 & 0.0039 & 0.004 & 0.0024 & 0.0014 & 0.0006 & 0.001 & 0.0014 \\
\hline & 2015 & 0.0044 & 0.004 & 0.0042 & 0.0025 & 0.0017 & 0.0006 & 0.001 & 0.0016 \\
\hline \multirow{2}{*}{ PRFRAC } & 2000 & 1.52 & 1.61 & 1.50 & 1.52 & 1.55 & 1.42 & 1.46 & 1.45 \\
\hline & 2015 & 1.53 & 1.61 & 1.50 & 1.53 & 1.56 & 1.43 & 1.47 & 1.45 \\
\hline \multirow{2}{*}{ DIVISION } & 2000 & 0.98 & 1.00 & 1.00 & 1.00 & 1.00 & 0.98 & 0.99 & 1.00 \\
\hline & 2015 & 0.98 & 1.00 & 1.00 & 1.00 & 1.00 & 0.98 & 1.00 & 1.00 \\
\hline \multirow{2}{*}{$\mathrm{AI}$} & 2000 & 83.39 & 44.46 & 81.37 & 66.55 & 68.53 & 94.99 & 88.29 & 26.09 \\
\hline & 2015 & 82.76 & 43.01 & 81.26 & 66.37 & 69.23 & 94.94 & 87.92 & 35.70 \\
\hline \multirow{2}{*}{ CHESION } & 2000 & 99.54 & 85.54 & 99.02 & 93.02 & 96.77 & 99.58 & 99.39 & 50.08 \\
\hline & 2015 & 99.49 & 85.00 & 99.02 & 93.00 & 97.75 & 99.57 & 99.31 & 63.39 \\
\hline
\end{tabular}

Notes: PLAND is landscape patch; PD is patch density; PRFRAC is perimeter fractal dimension index; CHESION is patch cohesion index; DIVISION is landscape dimension index; $\mathrm{AI}$ is aggregation index.

The patch area percentage reflects the percentage of a certain type of land patch area to the total land area. Overall, the percentage of patch in grassland, unused land, and sandy land was the highest three in the study area. The percentage of patch of grassland, unused land, and sandy land in 2000 was $29.27 \%, 22.44 \%$, and $21.16 \%$, respectively, while they changed to $28.6 \%, 22.21 \%$, and $21.08 \%$ in 2015 , respectively. Patch density can reflect the degree of fragmentation of the landscape. In 2000, the largest patch density was unused land, which was as high as $4 \%$. In 2015, the largest patch density was grassland, which was as high as $4.4 \%$. Landscape patch shape complexity can be represented by perimeter fractal dimension index, with values between 1-1.7. In general, the closer the perimeter fractal dimension index is to 1 , the closer the patch is to the rectangle, and the simpler the shape shows with the greater degree of human interference. The perimeter fractal dimension index of sand, Gobi, and unused land are all below 1.5 in 2000 and 2015 (Table 3), while the perimeter fractal dimension index of other land use types are all above 1.5. It indicates that human disturbance to sandy land, Gobi, and built-up areas is the highest. The landscape separation index is between 0 and 1 . When the landscape separation index is 0 , the landscape consists of a simple patch. When the value is close to 1 , it means that the landscape is close to be cut by urban roads or other factors, which means a high degree of landscape fragmentation. The landscape separation index for the year of 2000 and 2015 was between $0.98-1$, which shows that the degree of landscape segmentation in the study is serious. 
Table 3. Land use/cover change in Xinjiang from 2000 to 2015.

\begin{tabular}{|c|c|c|c|c|}
\hline Land Use/Cover Type & $2000 / 10^{4} \mathrm{~km}^{2}$ & $2015 / 10^{4} \mathrm{~km}^{2}$ & Change $/ 10^{4} \mathbf{k m}^{2}$ & Rate of Change/\% \\
\hline Cultivated land & 6.07 & 7.90 & 1.83 & $30.24 \%$ \\
\hline Forestry & 3.59 & 3.47 & -0.12 & $-3.36 \%$ \\
\hline Grassland & 48.26 & 47.13 & -1.12 & $-2.33 \%$ \\
\hline Water & 5.16 & 5.18 & 0.02 & $0.41 \%$ \\
\hline Built-up & 0.37 & 0.59 & 0.22 & $58.95 \%$ \\
\hline Unused land & 34.93 & 34.80 & -0.13 & $-0.37 \%$ \\
\hline Sandy land & 29.33 & 29.00 & -0.32 & $-1.10 \%$ \\
\hline Gobi & 36.93 & 36.55 & -0.38 & $-1.03 \%$ \\
\hline
\end{tabular}

The aggregation index reflects the connectivity between patches of each landscape type. The value is between 0 and 100. The smaller the value is, the more broken the landscape will be. The aggregation index of forestry areas and built-up areas is small. The aggregation index values of forestry areas and built-up areas were as low as 44.46 and 26.09 , respectively, in 2000. The aggregation index values of forestry areas and built-up areas in 2015 were 43.01 and 35.7, respectively. It shows that the landscape fragmentation of forestry areas and built-up areas is very high. Patch cohesion index reflects patch connectivity. The cohesion index of built-up areas is the worst in two years, and the values were 50.08 and 63.39 , respectively. The connectivity between other landscape types was much higher. The decrease of percentage of patches of grassland, unused land, and sandy land reflected the increase in human exploitation of natural resources. The percentage of patches of cultivated land and built-up areas has increased, which is the best embodiment of urbanization activities. Plaque density increased by landscape type, indicating an increased degree of fragmentation of the all landscape, which is highly consistent with rapid urbanization. Overall, the perimeter fractal dimension index of each landscape in 2000 was smaller than that in 2015, which indicates that patch shapes are becoming more and more complex, indicating the degree of fragmentation of landscape patches to some extent. The landscape separation index has not changed from 2000 to 2015. In addition to the increase in aggregation and cohesion indices of cultivated and built-up areas, other types of landscape aggregation indices are all decreasing. It indicates that the connectivity of other types of landscape is getting worse. As can be seen from the above analysis, with the increase of arable land and built-up areas, other types of landscape in the study are increasingly fragmented and isolated, which is the most direct embodiment of poor landscape connectivity caused by urbanization.

\subsection{Land Use and Landscape Changes}

\subsubsection{Analysis of Land Use Status in Xinjiang}

In 2015, grassland was the largest land type in Xinjiang, reaching as high as $28.63 \%$ (Figure 3). The grassland of Xinjiang is mainly distributed on the edge of Taklimakan desert in the south, the oasis in the northern foot of Mount Tian and the border along the northwest of the northern part of Mount Tian. The second proportion of land use types is unused land, accounting for $22.20 \%$, mainly distributed in Kunlun-Aljinshan northern foothills. The sand, Gobi, cultivated land, water, and forestry areas account for $21.14 \%, 17.62 \%, 4.8 \%, 3.15 \%$, and $2.11 \%$, respectively. The sandy land is flaky, mainly distributed in the Taklimakan desert in the south and the Gulbantungut desert in the north. The distribution of Gobi and unused land is similar, mainly with a banding distribution in the northern foothills of Mount Kunlun-Aljin. Because of the lack of water in Xinjiang, the water is distributed sporadically with a small area, mainly distributed in the central and northern foothills of Mount Tian and Mount Kunlun in the south. The cultivated land and forestry areas are scattered, and the forestry areas are mainly distributed in the three mountains, namely Mount Kunlun in the south, Mount Tian in the middle, and Mount Altai in the north. The smallest land category in Xinjiang is built-up areas, accounting for only $0.36 \%$, which is sporadic, mainly distributed in northern Xinjiang. The cultivated land is mainly around built-up areas, but also in sporadic distribution. 

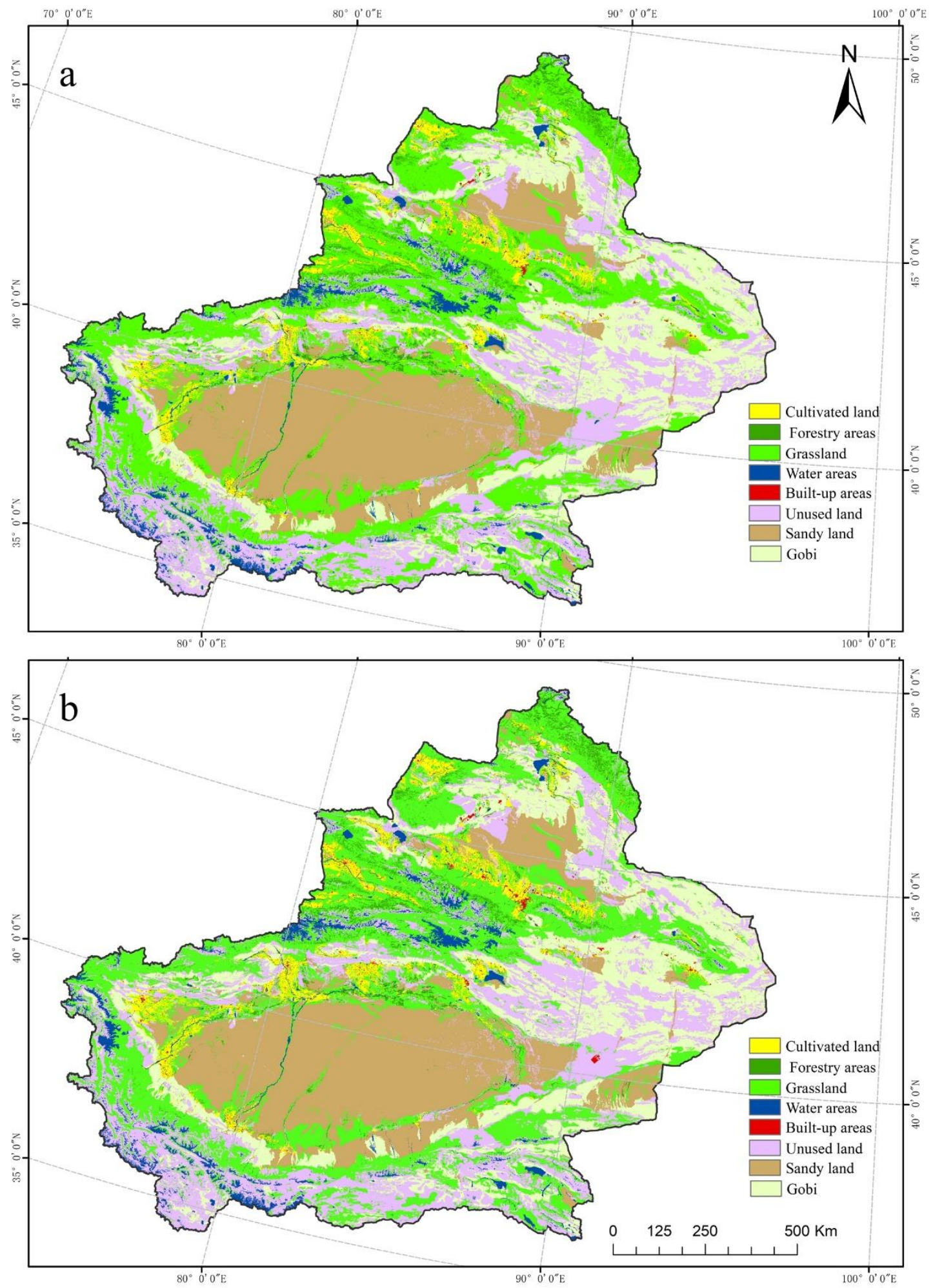

Figure 3. Xinjiang land use classification 2000-2015. (a) represents 2000, (b) represents 2015.

\subsubsection{Land Use/Cover Changes}

The spatial variation of land use/cover changes in different regions of Xinjiang from 2000 to 2015 is very different (Figure 4). It can be seen that the most significant land use changes in Xinjiang are the changes in forest land, grassland, unused land (decreasing trend), and cultivated land and construction land (increasing trend). Among them, the area of cultivated land has increased the 
most, with $2.04 \times 10^{4} \mathrm{~km}^{2}$ of cultivated land transformed from other land use types, which is the type with the most new added area of all land use types. This is because in recent years, Xinjiang has vigorously implemented immigration policies, attracting a large number of people from outside Xinjiang, which has led to the cultivation of large areas of Xinjiang's cultivated land. Because of the increase in population, there is an increasing demand for land types for construction land. As a result, cultivated land and construction land are expanding. The loss in forest land and grassland is serious, which lost $0.18 \times 10^{4} \mathrm{~km}^{2}$ and $1.43 \times 10^{4} \mathrm{~km}^{2}$, respectively. Xinjiang's dryness, little rain, heavy sandstorms, and poor soil texture are the main reasons for the decline of forest and grassland. In addition, overgrazing is also the main reason for the decline of forest and grassland. In the unused land, the sandy land lost $0.15 \times 10^{4} \mathrm{~km}^{2}$, the Gobi lost $0.35 \times 10^{4} \mathrm{~km}^{2}$, and the others lost $0.05 \times 10^{4} \mathrm{~km}^{2}$, respectively. However, the newly added area was very small. The water area lost $0.12 \times 10^{4} \mathrm{~km}^{2}$, but only gained $0.14 \times 10^{4} \mathrm{~km}^{2}$ simultaneously, showing a slight increase trend.

In general, the cultivated land and built-up areas in Xinjiang have increased rapidly, and the forest and grass, Gobi, and unused land have been greatly reduced. From 2000 to 2015, cultivated land in Xinjiang increased by $1.83 \times 10^{4} \mathrm{~km}^{2}(30.24 \%)$ (Table 3$)$.

Cultivated land has increased in all the municipal administrative districts of Xinjiang. The cultivated land expansion in Aksu and Kashar are particular obvious. The built-up areas in Xinjiang increased by $0.22 \times 10^{4} \mathrm{~km}^{2}$ (58.95\%) from 2000 to 2015 . The expansion of built-up areas in Bayinguleng Mongolia Autonomous district and Changji district is particularly huge. From 2000 to 2015 , Xinjiang's water areas increased by $0.02 \times 10^{4} \mathrm{~km}^{2}(0.41 \%)$, and the increase mainly occurred in the Bayinguleng Mongolia Autonomous district and the Fortala Mongolia Autonomous district. Contrary to the changing trend of cultivated land and built-up areas, forestry areas and grassland in Xinjiang decreased by $0.12 \times 10^{4} \mathrm{~km}^{2}(-3.36 \%)$ and $1.12 \times 10^{4} \mathrm{~km}^{2}(-2.23 \%)$, respectively, from 2000 to 2015. Moreover, the decline usually occurred in the areas where the cultivated land increased. The decrease of sandy, Gobi, and unused land reached $0.13 \times 10^{4} \mathrm{~km}^{2}(-1.10 \%), 0.32 \times 10^{4} \mathrm{~km}^{2}$ $(-1.03 \%)$, and $0.38 \times 10^{4} \mathrm{~km}^{2}(-0.37 \%)$, respectively. The loss of these lands usually occurred in the areas experiencing arable land and built-up areas expansion. As a whole, Xinjiang experienced significant built-up areas and cultivated land expansion, which mainly occurred in the central Xinjiang. In addition, these areas also experienced serious forest and grassland loss.

At city level, the cultivated land presents a significant increasing trend from 2000 to 2015 in most of the cities (Figure 5). Nevertheless, the cultivated land change in Wujiaqu, Urumqi, Shihezi, and Karamay Dushanzi is slight. The cultivated land expansion in Aksu, Kashi, Tacheng, Bayinguleng Mongolia Autonomous district, and Yining are as high as $0.21 \%, 0.17 \%, 0.14 \%, 0.14 \%$, and $0.06 \%$, respectively. Built-up areas have increased in each city district of Xinjiang, and the areas with rapid increase are Bayinguleng Mongolia Autonomous district and Changji District, with a change rate of $0.03 \%$ and $0.02 \%$, respectively. The change rate of Hami, Urumqi, Turpan, Tacheng, Yining, and Kashar is the same, with an increase of $0.01 \%$.

The decrease of grassland in Tacheng and Aksu district is as high as $0.13 \%$ and $0.12 \%$, respectively, followed by Bayinguleng Mongolia Autonomous district, Tacheng, and Yining, with a decrease of 0.09\%, $0.08 \%$, and $0.07 \%$, respectively. The largest three decreases in unused land were in Bayinguleng Mongol Autonomous district, Tacheng, and Aksu, with rates of $-0.06 \%,-0.04 \%$, and $-0.04 \%$, respectively. The fastest reduction in Gobi is in Altay, with a rate of $-0.07 \%$.

\subsection{Results of Resistance Surface Construction}

\subsubsection{Construction of Resistance Surface and Comprehensive Resistance Surface}

For the elevation resistance surface, it is higher in the Taklimakan desert edge in the south and around Altai Mountain in the north (Figures 6 and 7). The high slope resistance is mainly distributed in the three mountains in Xinjiang, including Mount Kunlun in the south, Mount Tian in the middle, and Mount Altai in the north. For the resistance surface of drainage, the resistance value of the fifth 
grade river is the largest, and the resistance value of the river above the third grade is small. For roads, the resistance surfaces of railways and national highways are larger, and the resistance surfaces of other roads are smaller. The biggest resistance surface of land use type is the desert zone, and the resistance surfaces of other places are smaller. The face value of the integrated resistance is large in the southern edge of the Taklimakan desert and major mountains, such as the northern Aljinshan and the central Mount Tian, followed by desert areas such as the Taklamakan desert and the Gulbantungut desert.
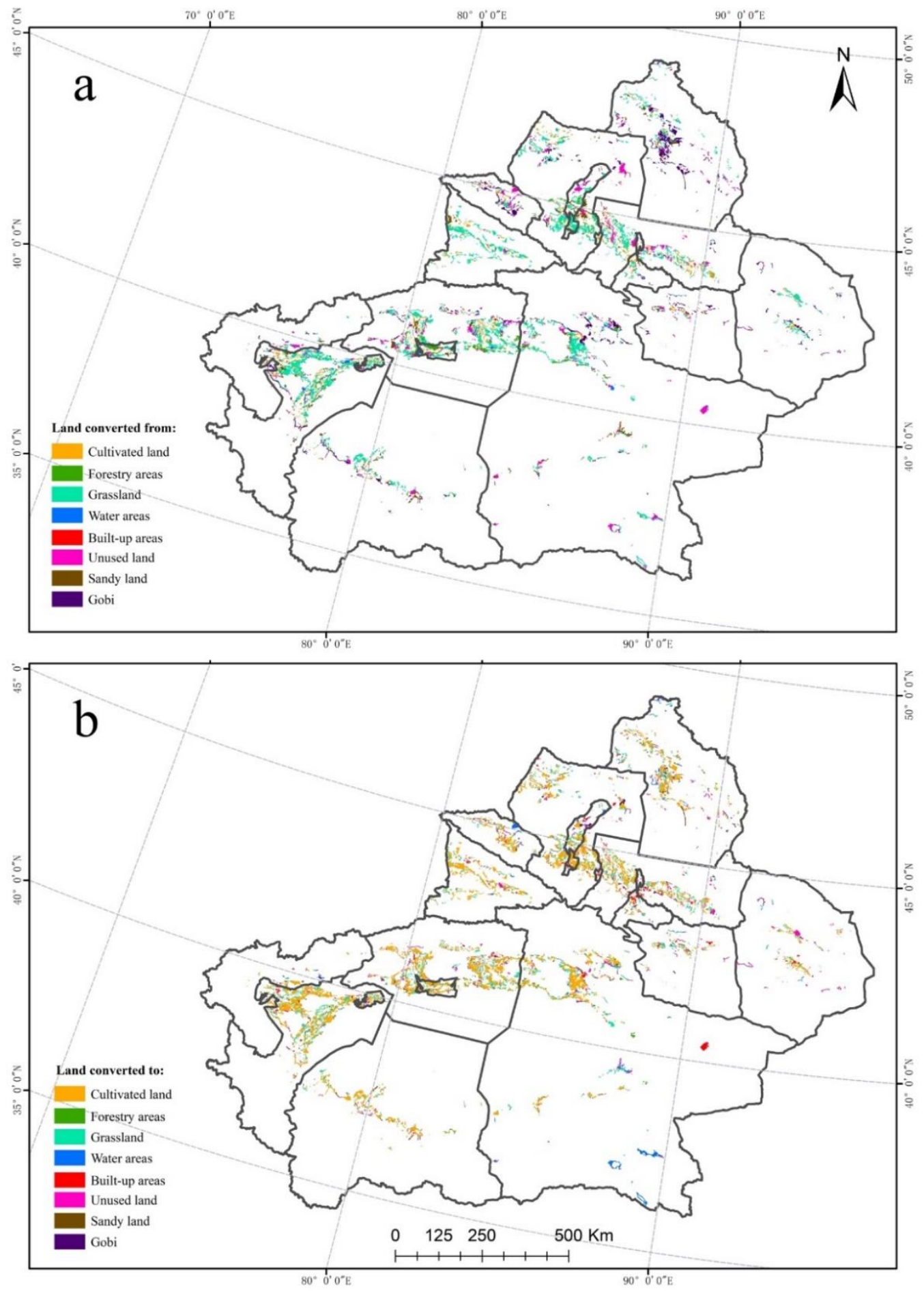

Figure 4. Transfer out (a) and transfer in (b) changes of land use/cover in Xinjiang from 2000 to 2015. 


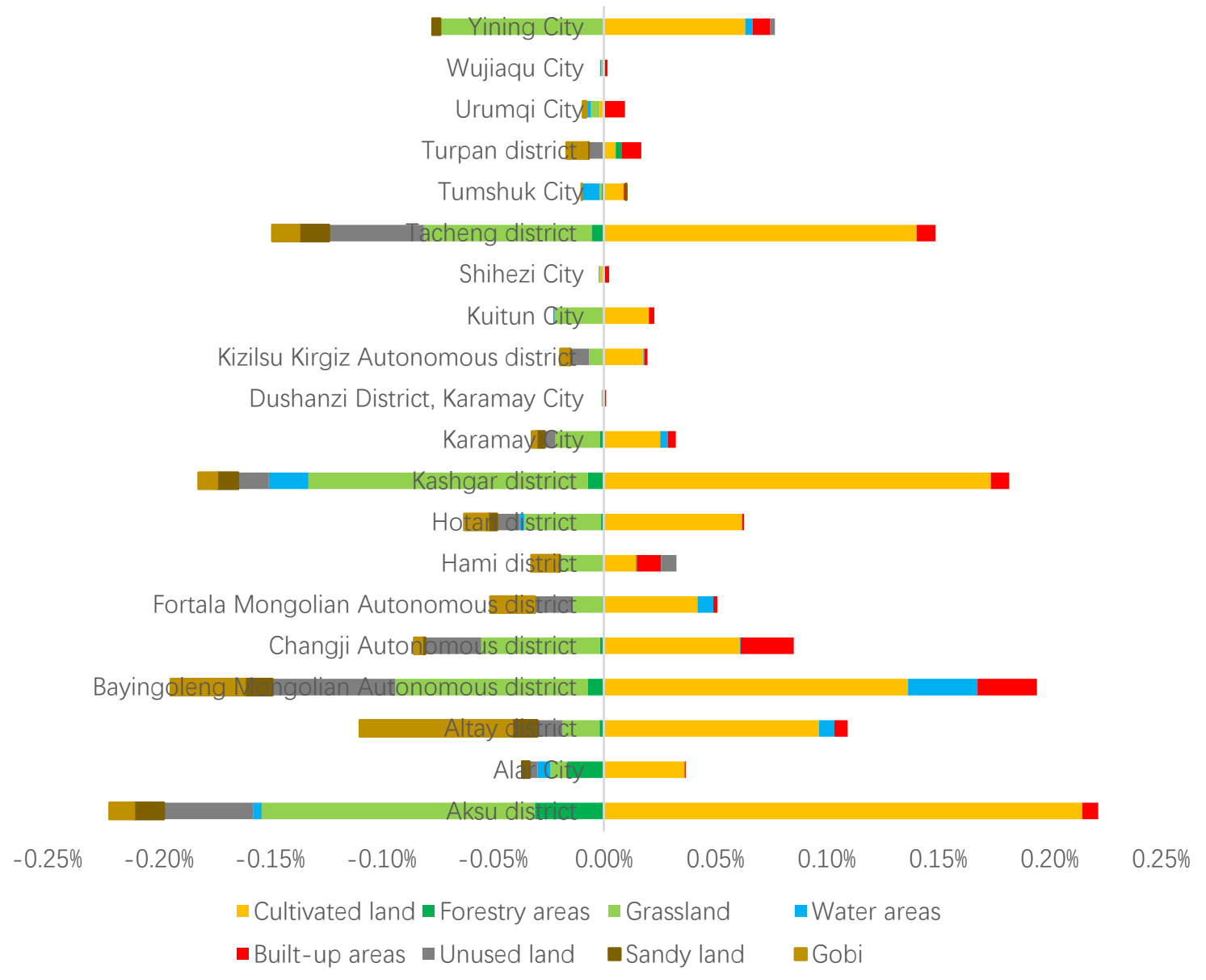

Figure 5. Land use/cover changes in different cities of Xinjiang, 2000-2015.

\subsubsection{Accumulated Resistance Surface}

The total resistance surface of the Taklimakan desert in the south and the Gulbantungut desert in the north is the largest (Figure 7), and the cumulative resistance value in other places is relatively small.

It can be seen that the higher the score, the greater the resistance to species migration and the more difficult the spread of information flow. The average cost value is between 350 and 400 . The areas with a higher comprehensive resistance surface in Xinjiang are at the edge of the desert, where the altitude and slope are relatively high (Figure $7 \mathrm{~b}$ ). Each pixel of the comprehensive resistance map has a value that reflects the energy consumption, difficulty, or death risk rate of passing through the pixel. The resistance value is usually determined by the combined characteristics of surface coverage or construction land density, water system, elevation, etc. When a species leaves a specific ecological source area, the cost-weighted distance will produce a cumulative resistance surface map. It can be seen that the largest cumulative resistance is in the Taklimakan Desert in the south and the Gurbantunggut Desert in the north (Figure 7c).

\subsection{Identification and Construction of Ecological Network in Xinjiang}

\subsubsection{Selection of Ecological Sources}

The ecological source patch gathers abundant species resources in the region where the ecological environment is good and the land use intensity is not high. The ecological source is usually an important channel for the migration and diffusion of biological species, which has very important ecological significance. 
According to the characteristics of the natural environment in Xinjiang, we choose nature reserves, geological parks, scenic spots, and forest parks as the ecological sources. The larger the ecological patches, the better the vegetation quality and vegetation coverage, and the more favorable for species' survival and migration. A total of 145 ecological patches were selected (Figure $8 \mathrm{a}$ ) with a total area of $55.30 \times 10^{4} \mathrm{~km}^{2}$, accounting for $33.60 \%$ of the total Xinjiang. The ecological sources are mainly distributed in areas with better natural environment quality, such as in forests and grasslands. In space, they are mainly distributed around the border of Xinjiang and the Tianshan Mountains.
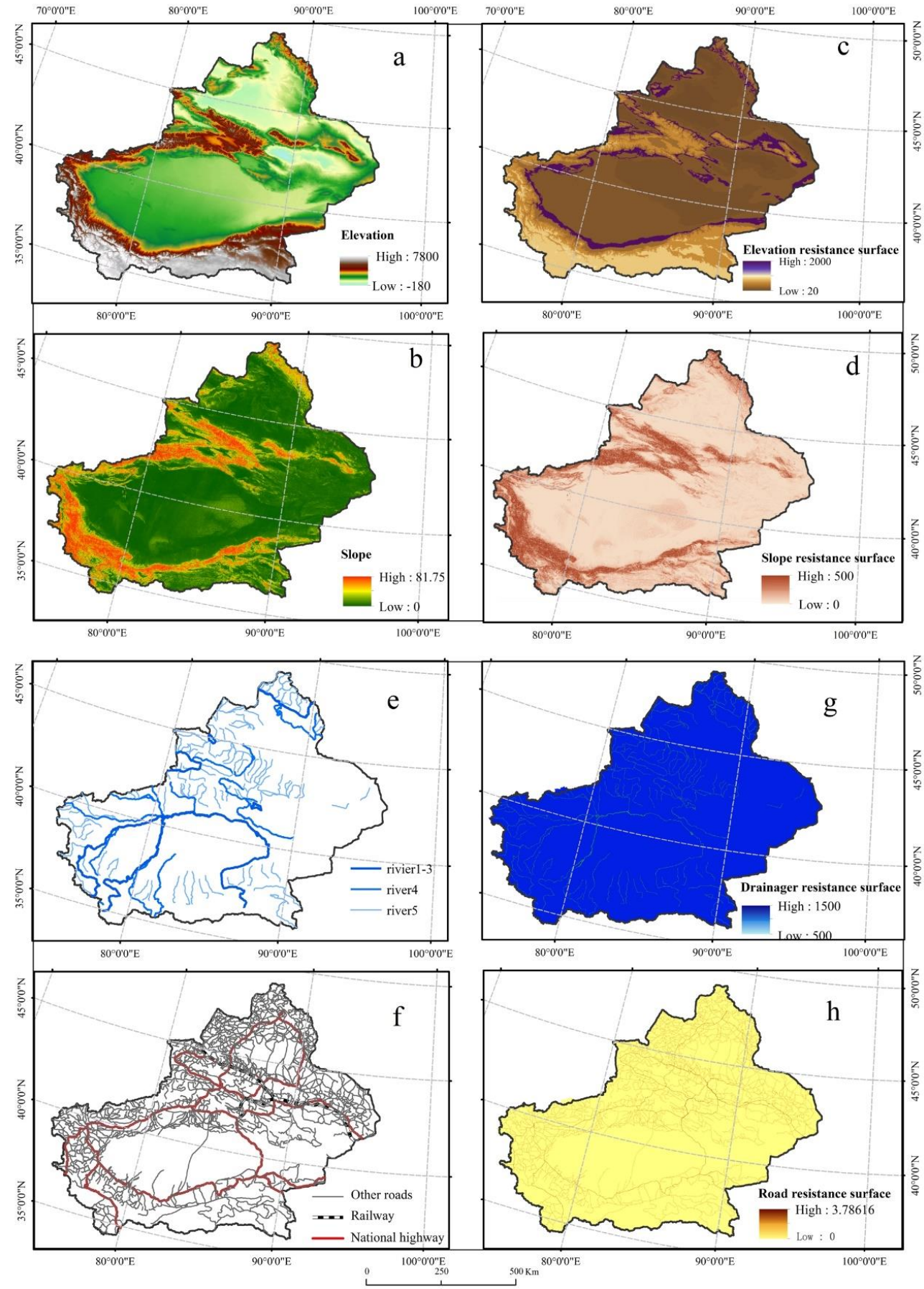

Figure 6. Distribution of landscape elements and corresponding resistance surfaces at all levels in Xinjiang $(\mathbf{a}, \mathbf{b}, \mathbf{e}, \mathbf{f})$ represent the elements of elevation, slope, drainage, and road, respectively; figure $(\mathbf{c}, \mathbf{d}, \mathbf{g}, \mathbf{h})$ represent the elevation resistance surface, slope resistance surface, drainage resistance surface, and road resistance surface, respectively. 


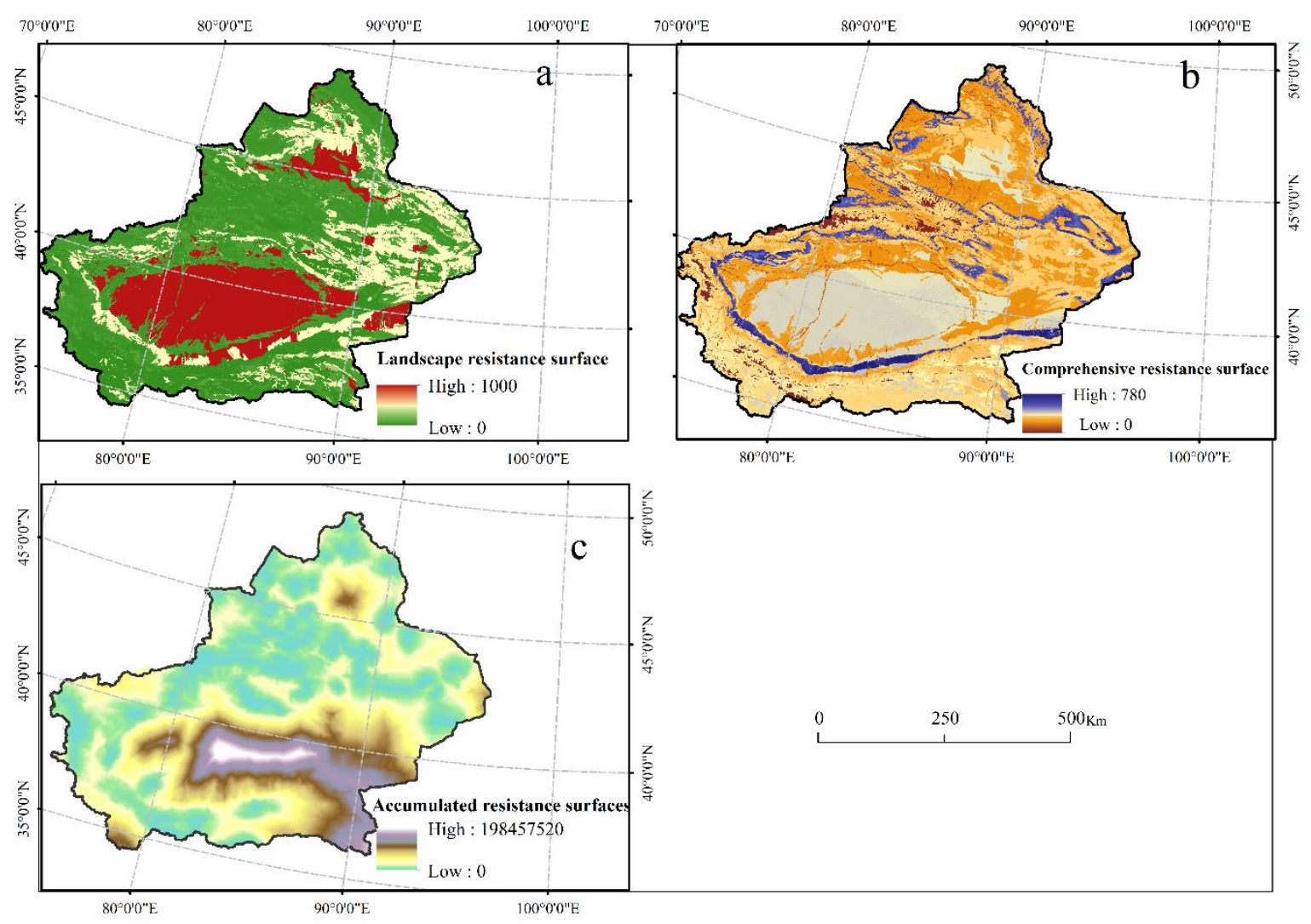

Figure 7. Landscape resistance surface (a), comprehensive resistance surface (b), and accumulated resistance surface $(c)$ in Xinjiang.

Along the western and southern border of Xinjiang, the nature reserves are distributed in a circle (Figure 8b), which is mainly in Bayinguleng Mongolia Autonomous Prefecture, Turpan, and Hami, with a total area of $10.65 \times 10^{4} \mathrm{~km}^{2}$. Besides nature reserves, forest parks, geological parks, and scenic spots are also distributed around the boundaries of Xinjiang, with a total area of $44.65 \times 10^{4} \mathrm{~km}^{2}$.

\subsubsection{Building a Potential Ecological Corridor}

Ecological corridors are an important part of the ecological network and are the main channels for dispersing the ecological flow of the landscape. They can guide the healthy and coordinated development of cities. Ecological corridors can effectively integrate various landscape ecological resources in the region. Ecological corridors can effectively connect the interior of Xinjiang. According to statistics, there are 296 potential corridors connecting 145 ecological source patches with a total length of $2.7 \times 10^{4} \mathrm{~km}$. The average length of the corridor is $90.98 \mathrm{~km}$ (Figure 9A). Xinjiang's ecological corridors are mainly concentrated in northern Xinjiang. These ecological corridors connect some important ecological sources in Xinjiang. Specifically, some short-distance ecological corridors connect these large patches together, while longer ecological corridors mainly connect distant ecological source patches. In this way, the ecological corridor effectively connects the patches of ecological sources in Xinjiang. 

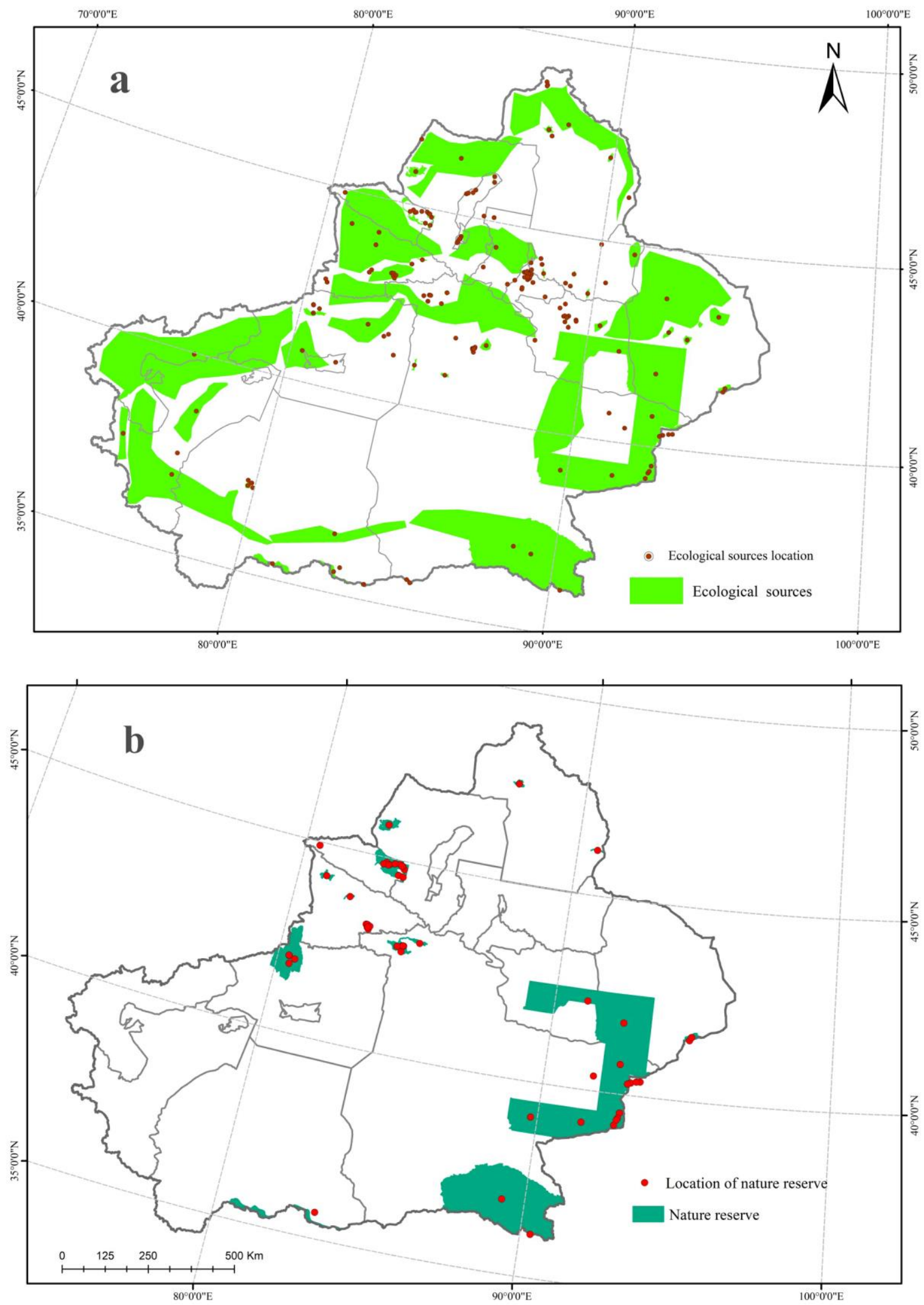

Figure 8. Distribution of ecological sources (a) and nature reserves (b) in Xinjiang. 


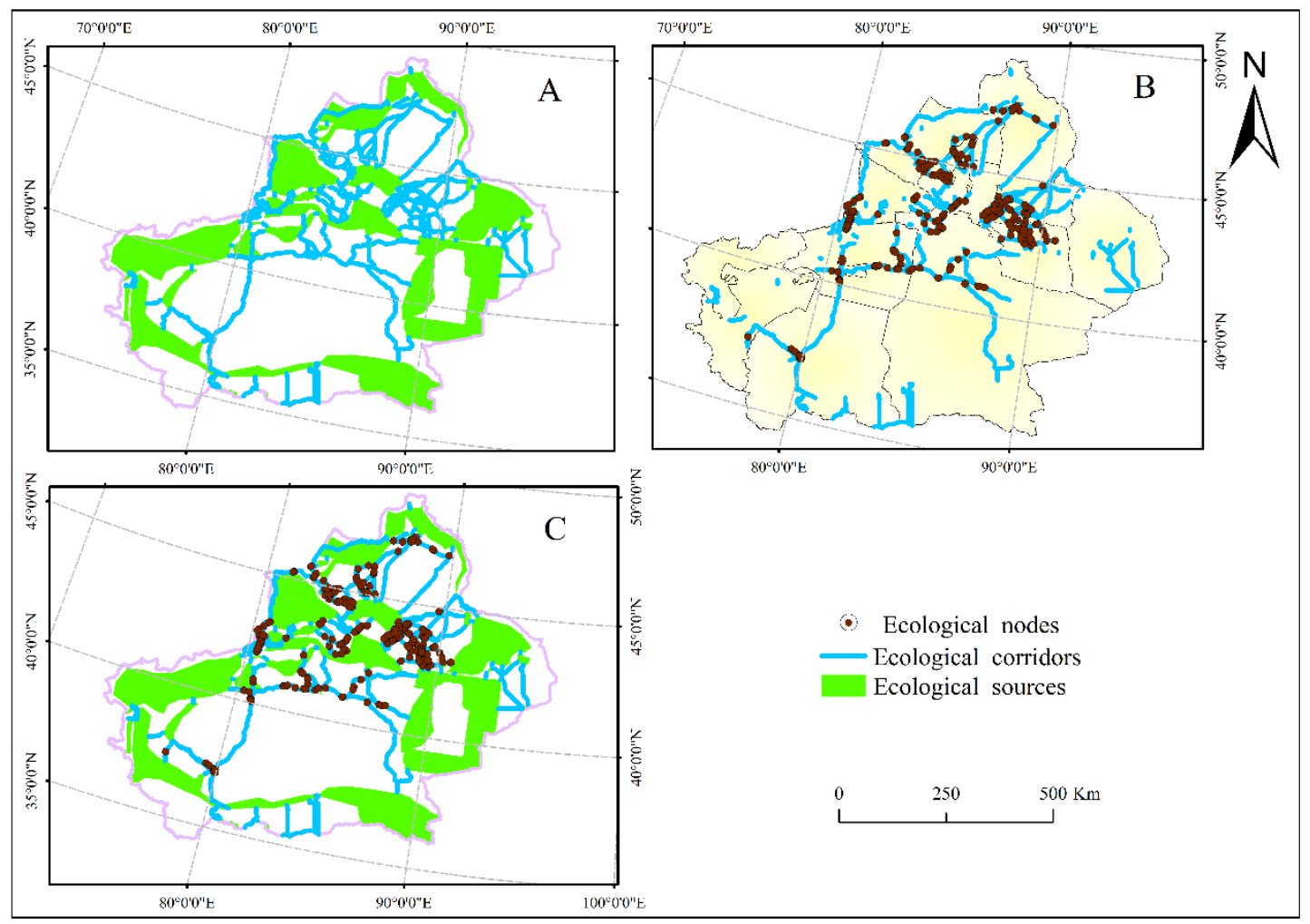

Figure 9. Spatial distribution of potential ecological corridors (A), ecological nodes (B), and ecological sources (C) in Xinjiang.

From the spatial distribution of ecological corridors, Xinjiang ecological corridors show the characteristics of "dense-north and sparse-south" in space. In Urumqi, Changji, Turpan, Tacheng, Kizilsu Kirgiz Autonomous Prefecture, Karamay, and Yining, the distribution of ecological corridors is the densest. The southern ecological corridor is located on the edge of the Taklimakan desert.

\subsubsection{Ecological Node Identification}

Ecological nodes are generally located at the weakest part of the ecological corridor, that is, the convergence of the least cost path and the least cost path. Ecological nodes can connect scattered and isolated patches, and play a vital role in the effective and rapid operation of ecological flows between ecological networks. The number, quality, and spatial distribution of ecological nodes all affect the time of species migration and the probability of successful migration. The ecological nodes of Xinjiang are mainly distributed in the northern part of the study area.

An ecological node is the intersection among ecological corridors, which can promote the diffusion of ecological flow in Xinjiang. According to the potential ecological corridor, we extracted 500 ecological nodes (Figure 9B). It can be seen that the number of ecological nodes in Urumqi, Turpan, Karamay, and Boltara Mongolia Autonomous Prefecture is high. These areas are the key areas of ecological construction and the most beneficial areas for ecological corridor construction.

\subsubsection{Spatial Distribution of Ecological Network in Xinjiang}

Overlapping the ecological sources, ecological corridors, and ecological nodes, the ecological network of Xinjiang is constructed (Figure 9C). The total length of ecological corridors in each city of Xinjiang varies greatly. As a whole, the ecological corridors in northern Xinjiang are dense, especially in the Turpan Basin and the northern slope of Mount Tian. The cities with dense corridors mainly include Urumqi, Turpan, and Aksu (Figure 10a), and the number of corridors is 142, 121, and 116, respectively, accounting for $14.13 \%, 12.04 \%$, and $11.54 \%$ of the total, respectively. Relatively speaking, the number 
of corridors in the Kizilsu Kirgiz Autonomous Prefecture, Kashi, and Hami district is small. They are as low as 7,8 , and 19 , respectively, accounting for $0.7 \%, 0.8 \%$, and $1.89 \%$ in turn. Hotan district has the longest total length of the ecological corridor (Figure 10b), which is $0.46 \times 10^{4} \mathrm{~km}$, accounting for $17.13 \%$ of the total length, followed by Bainler Mongolia Autonomous district, Aksu, and Tacheng, with the value of $0.45 \times 10^{4} \mathrm{~km}, 0.4 \times 10^{4} \mathrm{~km}$, and $0.3 \times 10^{4} \mathrm{~km}$, respectively, accounting for $17.01 \%$, $14.93 \%$, and $11.32 \%$ in turn.

a

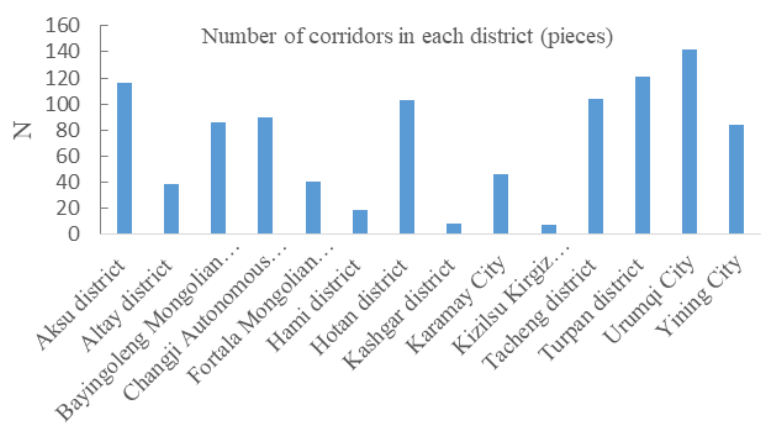

$\mathrm{b}$

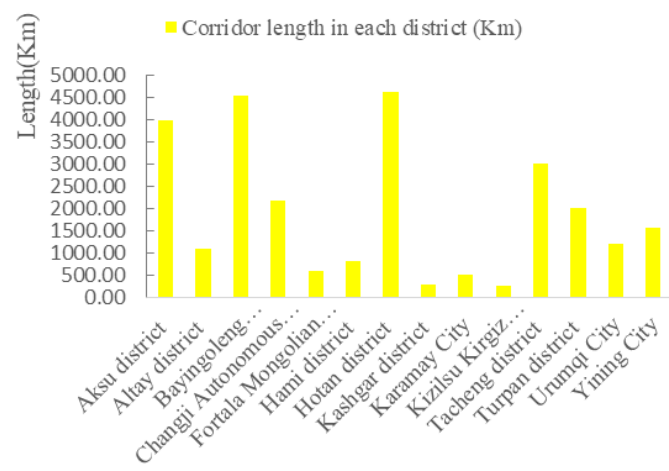

Figure 10. District statistics of the ecological corridor in Xinjiang. (a) represents the number of ecological corridors, and (b) represents the length of ecological corridors).

\section{Discussion}

\subsection{Comparison of Ecological Corridor Construction}

Ecological corridors connect broken and isolated ecological patches, which not only improve biodiversity, but also promote the high-speed and stable operation of the ecosystem. Comparing the results of our ecological corridor construction with the results of the previous researches, we found that the number of ecological corridors constructed in each region is different. In the ecologically fragile zone of Dengkou County of China, it has built 47,466 ecological corridors and extracted 1058 ecological nodes [70]. Qinghai has constructed 19 potential ecological corridors [26]. Using InVEST and the Least Cost Path Model (LCP), 4769 bird corridors and 3684 small mammal corridors were constructed in Wuhan [25].

As an example of urban green space ecological network planning, Nanchang of China constructed 165 corridors and extracted 118 ecological nodes [27]. In this paper, 296 ecological corridors are constructed to connect 145 ecological source patches. It can be seen that the number of ecological corridors in Xinjiang is relatively small comparing to its huge territory.

\subsection{The Causes of Changes in Land Use and Landscape Patterns}

Changes in land use types in Xinjiang in recent years have led to an increase in patch density in various landscape types, and patch shapes have become more and more complex, indicating that the fragmentation and isolation of regional landscapes has increased. Human activities played a key role in this process.

Urbanization is the main factor affecting the landscape pattern change [54,71]. With the increase of human activities, the landscape tends to become increasingly complicated, and the fragmentation of the landscape intensifies. For land use changes, built-up areas and arable land have increased significantly, while forest and grassland have decreased significantly. This is a direct consequence of the rapid development of urbanization and the increasing grazing activities. 


\subsection{The Reasons for the Spatial Distribution of Corridors}

The spatial distribution of the corridors is characterized by "density in the north and sparseness in the south". This is mainly because when we construct the ecological corridors, we construct the ecological corridors based on geographic elements such as rivers, roads, slopes, elevations, and land cover. In other words, the ecological corridor in this article is constructed based on the natural geographical conditions of the southern and northern Xinjiang. The better the natural geographical conditions, the higher the ecological suitability, and the denser the ecological corridors. Because the natural geographical conditions of northern Xinjiang are better than those of southern Xinjiang, the ecological corridors in northern Xinjiang are dense, while those in southern Xinjiang are sparse.

\section{Conclusions}

We analyzed the land use change and landscape pattern change in Xinjiang from 2000 to 2015. Then, the ecological corridor was built by Linkage Mapper corridor simulation software. Finally, the ecological network of Xinjiang was generated by using the ecological corridor, ecological source, and ecological node data. It was found that the land use change in Xinjiang from 2000 to 2015 resulted in the increase of patch density and complexity of patch shape, indicating the increase of fragmentation and isolation.

A total of 296 potential ecological corridors of Xinjiang have connected 145 ecological source patches with a total length of $2.7 \times 10^{4} \mathrm{~km}$. The average corridor length of Xinjiang is $90.98 \mathrm{~km}$ with 500 ecological nodes. The spatial distribution of ecological corridors shows the characteristics of "dense-north and sparse-south". The distribution of ecological corridors is consistent with the natural conditions in Xinjiang, which can prove the rationality of our research result and the applicability of our research method to some degree.

Author Contributions: Conceptualization, W.S.; methodology, Y.Z. and W.S.; formal analysis, Y.Z. and W.S.; investigation, W.S. and Y.Z.; resources, W.S.; writing — original draft preparation, Y.Z. and W.S.; writing一review and editing, W.S.; supervision, W.S. All authors have read and agreed to the published version of the manuscript.

Funding: This research was funded by the Second Tibetan Plateau Scientific Expedition and Research (Grant No. 2019QZKK0603), the Natural Science Foundation of Qinghai Province (2019-ZJ-7020), the Strategic Priority Research Program of Chinese Academy of Sciences (Grant No. XDA20040201), the Important Science \& Technology Specific Projects of Qinghai Province (2019-SF-A4-1), the National Natural Science Foundation of Qinghai Province (2019-ZJ-7020), the National Natural Science Foundation of China (Grant Nos. 41671177 and 42071233), the projects of Land Consolidation and Rehabilitation Center, Ministry of Natural Resource of China titled "Research on the Protection of the Grand Canal Ecosystem" and "Performance Evaluation and Improvement Suggestions for the Reuse Policy of Rural Inefficient Construction Land".

Conflicts of Interest: The authors declare no conflict of interest. The funders had no role in the design of the study; in the collection, analyses, or interpretation of data; in the writing of the manuscript; nor in the decision to publish the results.

\section{References}

1. Gao, Y.; Ma, L.; Liu, J.; Zhuang, Z.; Huang, Q.; Li, M. Constructing Ecological Networks Based on Habitat Quality Assessment: A Case Study of Changzhou, China. Sci. Rep. 2017, 7, 46073. [CrossRef] [PubMed]

2. Harris, L.D. The Fragmented Forest: Island Biogeography Theory and the Preservation of Biotic Diversity; University of Chicago Press: Chicago, IL, USA, 1984.

3. Zhang, Y.; Li, X.; Song, W. Determinants of cropland abandonment at the parcel, household and village levels in mountain areas of China: A multi-level analysis. Land Use Policy 2014, 41, 186-192. [CrossRef]

4. Vasconcelos, R.; Pujol-Buxó, E.; Llorente, G.A.; Saeed, A.; Carranza, S. Micro-Hotspots for Conservation: An Umbrella Tree Species for the Unique Socotran Reptile Fauna. Forests 2020, 11, 353. [CrossRef]

5. Starr, G.; Staudhammer, C.L.; Wiesner, S.; Kunwor, S.; Loescher, H.W.; Baron, A.F.; Whelan, A.; Mitchell, R.J.; Boring, L. Carbon Dynamics of Pinus palustris Ecosystems Following Drought. Forests 2016, 7, 98. [CrossRef]

6. Han, W.; Chang, Y.; Hu, Y.; Li, X.; Bu, R. Research advance in landscape pattern optimization. Chin. J. Ecol. 2005, 24, 1487-1492. 
7. Zeng, H.; Xia, J.; Zhang, L. The Current Status of Urban Landscape Ecology Study and Its Perspectives. Sci. Geogr. Sin. 2003, 23, 484-492.

8. Song, W.; Pijanowski, B.C. The effects of China'S cultivated land balance program on potential land productivity at a national scale. Appl. Geogr. 2014, 46, 158-170. [CrossRef]

9. Cook, E.A. Landscape structure indices for assessing urban ecological networks. Landsc. Urban. Plan. 2002, 58, 269-280. [CrossRef]

10. Pascualhortal, L.; Saura, S. Impact of spatial scale on the identification of critical habitat patches for the maintenance of landscape connectivity. Landsc. Urban. Plan. 2007, 83, 176-186. [CrossRef]

11. Carvalho, F.; Carvalho, R.; Mira, A.; Beja, P. Assessing landscape functional connectivity in a forest carnivore using path selection functions. Landsc. Ecol. 2016, 31, 1021-1036. [CrossRef]

12. Fischer, J.; Lindenmayer, D.B. Landscape modification and habitat fragmentation: A synthesis. Glob. Ecol. Biogeogr. 2007, 16, 265-280. [CrossRef]

13. Zetterberg, A.; Mortberg, U.; Balfors, B. Making graph theory operational for landscape ecological assessments, planning, and design. Landsc. Urban. Plan. 2010, 95, 181-191. [CrossRef]

14. Wenwen, X.; Xiang, S.; Xiaodong, Z.; Yueguang, Z.; Yangfan, L. Recognition of important ecological nodes based on ecological networks analysis: A case study of urban district of Nanjing. Acta Ecol. Sin. 2012, 32, 1264-1272. [CrossRef]

15. Chundi, C.; Colin, M.D.; Maria, I.; Glenn, S.H.; Shengjun, W. Identifying and evaluating functional connectivity for building urban ecological networks. Acta Ecol. Sin. 2015, 35, 18-35.

16. Muñoz-Adalia, E.J.; Sanz-Ros, A.V.; Flores-Pacheco, J.A.; Hantula, J.; Diez, J.J.; Vainio, E.J.; Fernández, M. Sydowia polyspora Dominates Fungal Communities Carried by Two Tomicus Species in Pine Plantations Threatened by Fusarium circinatum. Forests 2017, 8, 127. [CrossRef]

17. Graham Bennett, K.J.M. Review of Experience with Ecological Networks, Corridors and Buffer Zones; Technical Series; Secretariat of the Convention on Biological Diversity: Montreal, QC, Canada, 2006.

18. Linehan, J.R.; Gross, M.; Finn, J.T. Greenway planning: Developing a landscape ecological network approach. Landsc. Urban. Plan. 1995, 33, 179-193. [CrossRef]

19. Xia, L.; Zhang, Y.; Wu, Q.; Liu, L. Analysis of the ecological relationships of urban carbon metabolism based on the eight nodes spatial network model. J. Clean. Prod. 2017, 140, 1644-1651. [CrossRef]

20. Mo, W.; Wang, Y.; Zhang, Y.; Zhuang, D. Impacts of road network expansion on landscape ecological risk in a megacity, China: A case study of Beijing. Sci. Total Environ. 2017, 574, 1000-1011. [CrossRef]

21. Futuyma, D.J. Ecology and Evolution of Communities. Martin L. Cody, Jared M. Diamond. Q. Rev. Biol. 1977, 52, 108-109. [CrossRef]

22. Jongman, R.H.G.; Külvik, M.; Kristiansen, I. European ecological networks and greenways. Landsc. Urban. Plan. 2004, 68, 305-319. [CrossRef]

23. Jordán, F. A reliability-theory approach to corridor design. Ecol. Model. 2000, 128, 211-220. [CrossRef]

24. Williamson, J.C.; Bestelmeyer, B.T.; McClaran, M.P.; Robinett, D.; Briske, D.D.; Wu, X.B.; Fernández-Giménez, M.E. Can ecological land classification increase the utility of vegetation monitoring data? Ecol. Indic. 2016, 69, 657-666. [CrossRef]

25. Tang, Y.; Gao, C.; Wu, X. Urban Ecological Corridor Network Construction: An Integration of the Least Cost Path Model and the InVEST Model. Isprs Int. J. Geo-Inf. 2020, 9, 33. [CrossRef]

26. Shi, F.; Liu, S.; Sun, Y.; An, Y.; Zhao, S.; Liu, Y.; Li, M. Ecological network construction of the heterogeneous agro-pastoral areas in the upper Yellow River basin. Agric. Ecosyst. Environ. 2020, 302, 107069. [CrossRef]

27. Li, H.; Chen, W.; He, W. Planning of Green Space Ecological Network in Urban Areas: An Example of Nanchang, China. Int. J. Environ. Res. Public Health 2015, 12, 12889-12904. [CrossRef] [PubMed]

28. Zhao, S.-M.; Ma, Y.-F.; Wang, J.-L.; You, X.-Y. Landscape pattern analysis and ecological network planning of Tianjin City. Urban. For. Urban. Green. 2019, 46, 126479. [CrossRef]

29. Li, F.; Wang, R.; Paulussen, J.; Liu, X. Comprehensive concept planning of urban greening based on ecological principles: A case study in Beijing, China. Landsc. Urban. Plan. 2005, 72, 325-336. [CrossRef]

30. Dupras, J.; Marull, J.; Parcerisas, L.; Coll, F.; Gonzalez, A.; Girard, M.; Tello, E. The impacts of urban sprawl on ecological connectivity in the Montreal Metropolitan Region. Environ. Sci. Policy 2016, 58, 61-73. [CrossRef]

31. Kong, Y. Landscape ecological security patterns in biological conservation. Acta Ecol. Sin. 1999, 9, 8-15.

32. Zhang, L.; Chen, Y.; Men, M.; Xu, H. Assessing method for regional ecological connectivity and its application based on GIS. Trans. Chin. Soc. Agric. Eng. 2014, 30, 218-226. 
33. Zhang, X.F.; Wang, Y.L.; Li, G.C.; Wu, J.; Li, Z. Landscape Functions Network Construction and Application in Watershed Scale: A Case Study on Taiwan Wuxi Watershed. Acta Geogr. Sin. 2005, 60, 974-980.

34. Pang, X.; Mörtberg, U.; Sallnäs, O.; Trubins, R.; Nordström, E.-M.; Böttcher, H. Habitat network assessment of forest bioenergy options using the landscape simulator LandSim-A case study of Kronoberg, southern Sweden. Ecol. Model. 2017, 345, 99-112. [CrossRef]

35. Dai, C.; Guo, H.C.; Tan, Q.; Ren, W. Development of a constructed wetland network for mitigating nonpoint source pollution through a GIS-based watershed-scale inexact optimization approach. Ecol. Eng. 2016, 96, 94-108. [CrossRef]

36. Dietz, M.S.; Belote, R.T.; Aplet, G.H.; Aycrigg, J.L. The world's largest wilderness protection network after 50years: An assessment of ecological system representation in the U.S. National Wilderness Preservation System. Biol. Conserv. 2015, 184, 431-438. [CrossRef]

37. Accorsi, R.; Cholette, S.; Manzini, R.; Pini, C.; Penazzi, S. The land-network problem: Ecosystem carbon balance in planning sustainable agro-food supply chains. J. Clean. Prod. 2016, 112, 158-171. [CrossRef]

38. Wang, G.; Wang, W.; Zhou, H. The Planning of Urban Fundamental Ecological Controlling Area: The Case of Guangzhou. Urban. Plan. Forum 2014, 159, 526-539.

39. Rongbo, X.; Guo'en, W.; Yongjun, A. Guangzhou green space plan for the target of livable city. Ciry Plan. Rev. 2009, 33, 64-68.

40. Yu, D.; Xun, B.; Shi, P.; Shao, H.; Liu, Y. Ecological restoration planning based on connectivity in an urban area. Ecol. Eng. 2012, 46, 24-33. [CrossRef]

41. Noss, R.F.; Harris, L.D. Nodes, networks, and MUMs: Preserving diversity at all scales. Environ. Manag. 1986, 10, 299-309. [CrossRef]

42. Nian Xing, Z.; Kong Jian, Y.; Zhen Fang, H. Perspectives on greenway development. Acta Ecol. Sin. 2006, 26, 3108-3116.

43. Peng, J.; Zhao, H.; Liu, Y. Urban ecological corridors construction: A review. Acta Ecol. Sin. 2017, 37, 23-30. [CrossRef]

44. Jiang, M.; Wu, H.; Lu, X.; Zhu, B.G. Theory, mode and practice for the design of wetland ecological corridorA case of Nongjiang River wetland ecological corridor, the Sanjiang Plain. Wetl. Sci. 2009, 7, 99-105.

45. Zong, Y.G.; Yi, Z.S.; Ping, P.; Chao, L.; Hua, G.R.; Cheng, H.C. Perspective of road ecology development. Acta Ecol. Sin. 2003, 23, 2396-2405.

46. Zhou Huafeng, F.B. Ecological structure of landscape and biodiversity protection. Sci. Geogr. Sci. 1998, 18, 472-478.

47. Yu, K.J.; Li, W.; Li, D.H.; Li, C.B.; Liu, H.L. Suitability analysis of heritage corridor in rapidly urbanizing region:a case study of Taizhou City. Geogr. Res. 2005, 24, 69-76.

48. Kong-Jian, Y.U.; Wang, S.S.; Di-Hua, L.I. The function of ecological security patterns as an urban growth framework in Beijing. Acta Ecol. Sin. 2009, 23, 1189-1204.

49. Li, W.M. Effects of urban corridor changes on urban landscape in Guangzhou city. Geogr. Territ. Res. 1999, $15,76-80$.

50. Hsiaofei, C.; Yanglin, W.; Zhengguo, L. Landscape pattern optimization based upon the concept of landscape functions network:a case study in Taiwan, China. Acta Ecol Sin. 2005, 25, 1707-1713.

51. Fábos, J.G. Greenway planning in the United States: Its origins and recent case studies. Landsc. Urban. Plan. 2004, 68, 321-342. [CrossRef]

52. Turner, T. Greenways, blueways, skyways and other ways to a better London. Landsc. Urban. Plan. 1995, 33, 269-282. [CrossRef]

53. Toccolini, A.; Fumagalli, N.; Senes, G. Greenways planning in Italy: The Lambro River Valley Greenways System. Landsc. Urban. Plan. 2006, 76, 98-111. [CrossRef]

54. State Council Bulletin. State Council on Further Promoting the Whole Country Notice of Green Passage Construction. Available online: http://www.gov.cn/gongbao/content/2000/content_60549.htm (accessed on 11 October 2000).

55. Jim, C.; Chen, S. Comprehensive greenspace planning based on landscape ecology principles in compact Nanjing city, China. Landsc. Urban. Plan. 2003, 65, 95-116. [CrossRef]

56. Kong, F.; Yin, H.; Nakagoshi, N.; Zong, Y. Urban green space network development for biodiversity conservation: Identification based on graph theory and gravity modeling. Landsc. Urban. Plan. 2010, 95, 16-27. [CrossRef] 
57. Yin, H.; Kong, F.; Qi, Y.; Wang, H.; Zhou, Y.; Qin, Z. Developing and optimizing ecological networks in urban agglomeration of Hunan Province, China. Acta Ecol. Sin. 2011, 31, 2863-2874.

58. Xie, H.W.; Zhou, N.X.; Guan, J. The construction and optimization of ecological networks based on natural heritage sites in Jiangsu Province. Shengtai Xuebao Acta Ecol. Sin. 2014, 34, 6692-6700.

59. Remote Sensing Monitoring Data of Land Use Status in China. Available online: http://www.resdc.cn/data. aspx?DATAID=99 (accessed on 20 July 2020).

60. DEM Digital Elevation Data. Available online: http://www.gscloud.cn/sources/?cdataid=302\&pdataid=10 (accessed on 15 July 2020).

61. Chinese Academy of Sciences Resources Environment Data Center. Available online: http://www.resdc.cn/ data.aspx?DATAID=226 (accessed on 2 July 2020).

62. Map API Tool. Available online: http://geo.lucikehao.com/ (accessed on 1 July 2020).

63. Song, W.; Deng, X. Land-use/land-cover change and ecosystem service provision in China. Sci. Total Environ. 2017, 576, 705-719. [CrossRef]

64. Liu, S.; Dong, Y.; Cheng, F.; Zhang, Y.; Hou, X.; Dong, S.; Coxixo, A. Effects of road network on Asian elephant habitat and connectivity between the nature reserves in Xishuangbanna, Southwest China. J. Nat. Conserv. 2017, 38, 11-20. [CrossRef]

65. Yu, F.; Xue, L.; Sun, C.; Zhang, C. Product transportation distance based supplier selection in sustainable supply chain network. J. Clean. Prod. 2016, 137, 29-39. [CrossRef]

66. Yu, J.; Yang, Z.; Wang, N.-F. Further results on structural stability and robustness to bounded rationality. J. Math. Econ. 2016, 67, 49-53. [CrossRef]

67. Yu, Q.; Yue, D.; Wang, J.; Zhang, Q.; Li, Y.; Yu, Y.; Chen, J.; Li, N. The optimization of urban ecological infrastructure network based on the changes of county landscape patterns: A typical case study of ecological fragile zone located at Deng Kou (Inner Mongolia). J. Clean. Prod. 2017, 163, S54-S67. [CrossRef]

68. Yu, Q.; Yue, D.; Yang, D.; Ma, H.; Zhang, Q.; Yin, B. Layout optimization of ecological nodes based on BCBS model. Trans. Chin. Soc. Agric. Mach. 2016, 47, 330-336.

69. Linkage Mapper. Available online: http://www.circuitscape.org/linkagemapper (accessed on 1 July 2020).

70. Yu, Q.; Yue, D.; Wang, Y.; Kai, S.; Fang, M.; Ma, H.; Zhang, Q.; Huang, Y. Optimization of ecological node layout and stability analysis of ecological network in desert oasis: A typical case study of ecological fragile zone located at Deng Kou County(Inner Mongolia). Ecol. Indic. 2018, 84, 304-318. [CrossRef]

71. Kline, J.D.; Moses, A.; Alig, R.J. Integrating Urbanization into Landscape-level Ecological Assessments. Ecosystems 2001, 4, 3-18. [CrossRef]

Publisher's Note: MDPI stays neutral with regard to jurisdictional claims in published maps and institutional affiliations.

(C) 2020 by the authors. Licensee MDPI, Basel, Switzerland. This article is an open access article distributed under the terms and conditions of the Creative Commons Attribution (CC BY) license (http://creativecommons.org/licenses/by/4.0/). 